\title{
Combination Vascular Delivery of Herpes Simplex Oncolytic Viruses and Amplicon Mediated Cytokine Gene Transfer Is Effective Therapy for Experimental Liver Cancer
}

\author{
Jonathan S. Zager, ${ }^{1}$ Keith A. Delman, ${ }^{1}$ Sandeep Malhotra, ${ }^{1}$ Michael I. Ebright, ${ }^{1}$ Joseph J. Bennett, ${ }^{1}$ \\ Tara Kates, ${ }^{1}$ Mark Halterman, ${ }^{2}$ Howard Federoff, ${ }^{2}$ and Yuman Fong ${ }^{1}$ \\ ${ }^{1}$ Department of Surgery, Hepatobiliary Division, Memorial Sloan-Kettering Cancer Center, New York, \\ New York, USA \\ ${ }^{2}$ Departments of Neurology and Medicine, University of Rochester Medical Center, Rochester, \\ New York, USA
}

Accepted April 2, 2001

\begin{abstract}
Background: Herpes simplex type I (HSV)-based vectors have been used experimentally for suicide gene therapy, immunomodulatory gene delivery, and direct oncolytic therapy. The current study utilizes the novel concept of regional delivery of an oncolytic virus in combination with or serving as the helper virus for packaging herpes-based amplicon vectors carrying a cytokine transgene, with the goal of identifying if this combination is more efficacious than either modality alone.

Materials and Methods: A replication competent oncolytic HSV (G207) and a replication incompetent HSV amplicon carrying the gene for the immunomodulatory cytokine IL-2 (HSV-IL2) were tested in murine syngeneic colorectal carcinoma and in rat hepatocellular carcinoma models. Liver tumors were treated with vascular delivery of (1) phosphate-buffered saline (PBS), (2) G207, (3) HSV-IL2,
\end{abstract}

(4) G207 and HSV-IL2 mixed in combination (mG207/HSVIL2), and (5) G207 as the helper virus for packaging the construct HSV-IL2 (pG207/HSV-IL2).

Results: Tumor burden was significantly reduced in all treatment groups in both rats and mice treated with highdose G207, HSV-IL2, or both $(p<0.02)$. When a low dose of virus was used in mice, anti-tumor efficacy was improved by use of G207 and HSV-IL2 in combination or with HSV-IL2 packaged by G207 ( $p<0.001)$. This improvement was abolished when $\mathrm{CD}^{+}$and $\mathrm{CD} 8^{+}$lymphocytes were depleted, implying that the enhanced anti-tumor response to low-dose combined therapy is immune mediated.

Conclusions: Vascular regional delivery of oncolytic and amplicon HSV vectors can be used to induce improved anti-tumor efficacy by combining oncolytic and immunostimulatory strategies.

\section{Introduction}

A variety of herpes simplex virus type 1 (HSV)-based therapies have demonstrated encouraging results in experimental animal models of cancer (1-8). One approach uses replication incompetent amplicon herpes vectors for the delivery of therapeutic transgenes including immunomodulatory cytokines, prodrugs, or tumor suppressor genes $(2,8-14)$. Other viral antineoplastic strategies employ replication competent oncolytic viruses that selectively infect and lyse tumor cells $(4,6,7,15-17)$. The current study explores the combined use of replication competent HSV as oncolytic agents along with replicationincompetent HSV amplicons as gene transfer vehicles. This approach potentially provides great flexibility in tailoring combinations of biological therapies for cancer. We and others have previously

Address correspondence and reprint requests to: Yuman Fong, MD, Department of Surgery, Hepatobiliary Division, Memorial Sloan-Kettering Cancer Center, 1275 York Avenue New York, New York 10021. Phone: (212) 639-2016; fax: (212) 639-4031; e-mail: fongy@mskcc.org shown the ability of such combinations of HSV vectors to produce regression of cancers after direct intratumoral injection of flank tumors $(9,18,19)$. The current study is an extension of theses previous studies and demonstrates in two clinically relevant models that vascular delivery of these agents can be combined. Furthermore, these studies demonstrate that the oncolytic virus can be used in the packaging of HSV amplicon to produce a viral mixture that is effective cancer therapy $(11,12,19,20)$.

\section{Materials and Methods Cells}

A murine colon cancer cell line (CT26) and a rat hepatoma cell line (Morris hepatoma McA-R-7777) were used in this study. Both Morris hepatoma and CT26 cell lines were obtained from the American Type Culture Collection (ATCC, Rockville, MD, USA). Morris hepatoma cells were maintained in DMEM supplemented with high glucose, $6.25 \% \mathrm{fe}$ tal calf serum (FCS), and $5 \mathrm{mM}$ L-glutamine. CT26 cells were maintained in RPMI 1640 supplemented 
with $10 \%$ FCS, $5 \mathrm{mM}$ nonessential amino acids, $100 \mu \mathrm{g} / \mathrm{ml}$ penicillin, and $100 \mu \mathrm{g} / \mathrm{ml}$ streptomycin.

\section{Viruses}

Herpes Amplicon Vector The replication defective herpes simplex amplicon vectors expressing IL-2 (HSV-IL2) were constructed by directionally cloning the IL-2 genes into HSVPrPUC as previously described $(9,13,21,22)$. To package amplicon, RR I cells were transfected by adding Lipofectin (GIBCO-BRL, Carlsbad, CA 92008), waiting 5 min and then adding the amplicon DNA solution dropwise. Approximately $20 \mathrm{hr}$ after transfection, the D30 EBA helper virus was added to achieve a multiplicity of infection (MOI) of 0.2 . After $1 \mathrm{hr}$, additional media containing 5\% FCS was added and amplicon virus stocks harvested 2 days later.

The amplicon to helper virus ratio was determined by titering each component separately. The helper virus was titered using a standard plaque assay, and the amplicon was titered by a slot blot assay (9). Briefly, the amplicon titers for both HSV-IL2 and HSV-LacZ were calculated from the density of the bands seen on a slot blot apparatus exposed to $\mathrm{x}$-ray film and then scanned densitometrically at various timed exposures. The HSV-IL2 titer was calculated relative to HSV-LacZ, given that this latter amplicon was also titered by a plaque assay (blue forming units on NIH-3T3 cells) (9).

G207 Virus The G207 virus, a gift from Drs. Rabkin and Martuza, was constructed as previously described (23). Briefly, G207 is a multimutated type-1 herpes simplex (HSV-1) virus derived from the laboratory wild-type F strain parent virus. Viral ribonucleotide reductase is inactivated by inserting the lacZ marker gene into the ICP6 sequence of the parent virus genome, and both copies of the $\gamma_{1} 34.5$ neurovirulence genes were deleted.

The G207 packaged amplicon vector (pG207/ HSV-IL2) was produced and titered as described with the G207 virus substituted for the D30 EBA helper virus (9).

The amplicon packaging process routinely produces titers of virus approximately $10^{7}$ particles $/ \mathrm{ml}$. The amplicon:helper ratio varies from 0.5 to 1.0. The dose of virus used for the mG207/HSV-IL2 group was calculated based on the results of the titering of helper virus (G207):amplicon (HSV-IL2) in the pG207/HSV-IL2 group, as described. Because the ratio of amplicon to helper virus was approximately 1 in both the HSV-IL2 and pG207/HSVIL2 groups, we used a ratio of 1:1 of G207: HSV-IL2 mixed together in the mG207/HSV-IL2 group (Table 1).

\section{In Vitro Cytotoxicity}

To measure the cytotoxicity of G207, in vitro cytotoxicity assays were performed. G207, HSV-IL2, mG207/HSV-IL2, or pG207/HSV-IL2 were added to subconfluent layers of CT-26 or Morris hepatoma cells in 12-well flat bottom plates (Costar, Corning Inc., Corning, NY, USA). In each well, $5 \times 10^{4}$ cells were plated. The respective viruses were added $12 \mathrm{hr}$ later at various MOI. Morris hepatoma cells were infected at MOIs of $0.01,0.1$, and 1 , and CT26 cells, which are slightly more resistant to infection with virus, were infected with MOIs of 0.1 , 1, and 5.0. For the mG207/HSV-IL2 and pG207/ HSV-IL2 groups, the ratio of G207: HSV-IL2 used to infect the cells was kept constant at $1: 1$. Cell viability was measured by counting live cells via trypan blue exclusion at 24-hr intervals, carried out to $192 \mathrm{hr}$. All assays were performed in triplicate.

\section{In Vitro IL-2 Production}

IL-2 production from cells infected in vitro by G207 alone, HSV-IL2, mG207/HSV-IL2, and pG207/ HSV-IL2 was measured by enzyme-linked immunosorbent assay (ELISA). Supernatants were harvested at 24-hr intervals from all four treatment groups at the different MOIs for both Morris hepatoma and CT-26 cell lines. IL-2 production

Table 1. Summary of the different oncolytic virus and amplicon combinations used explaining the composition and ratio of G207 to HSV-IL2 amplicon of the injectate

\begin{tabular}{lll}
\hline Vector Listed in Text Composition & Comments
\end{tabular}

\begin{tabular}{lll}
\hline G207 & $\begin{array}{l}\text { G207 alone } \\
\text { Interleukin } 2 \text { amplicon }\end{array}$ & $\begin{array}{l}\text { An attenuated, replication competent, oncolytic HSV-1. } \\
\text { A replication defective HSV vector carrying the IL-2 } \\
\text { gene for gene transfer. }\end{array}$ \\
mG207/HSV-IL2 & $\begin{array}{l}\text { A mixture of G207 virions } \\
\text { as well as HSV-IL2 vectors }\end{array}$ & $\begin{array}{l}\text { This mixture is injected as two separate particles } \\
\text { at the same time. The ratio of G207:HSV-IL2 is } 1 .\end{array}$ \\
PG207/HSV-IL2 & $\begin{array}{l}\text { Amplicon HSV-IL2 produced by } \\
\text { using G207 as the helper virus for } \\
\text { viral packaging }\end{array}$ & $\begin{array}{l}\text { This combination enables the G207 particle to act as } \\
\text { the helper virus for production of HSV amplicon, } \\
\text { thereby producing a mixture of G207 and amplicon }\end{array}$ \\
& $\begin{array}{l}\text { HSV-IL2 with no other helper viruses present. } \\
\text { The ratio of G207:HSV-IL2 is } 1 .\end{array}$
\end{tabular}


was determined by ELISA ( $\mathrm{R} \& \mathrm{D}$ systems, Minneapolis, MN, USA).

\section{Establishment and Treatment of Hepatic} Metastases in Rats

All animal work was performed under guidelines established by the Memorial Sloan-Kettering Cancer Center Institutional Animal Care and Use Committee. Buffalo rats were purchased from Charles River Laboratories (Wilmington, MA, USA). The rat model of hepatic metastases is well established in this laboratory (4). Three weeks after intrasplenic injection of $5 \times 10^{5}$ Morris hepatoma cells, these rats reliably develop between 150 and 250 countable liver nodules. Blood draining from the spleen directly enters the portal circulation, and therefore, intrasplenic injection is a very reliable method of delivery of agents into the portal vasculature. The spleen is not removed, however, as to not interfere with the immune response to the tumor in the liver. Male Buffalo rats (200-250 g) were housed two per cage and allowed food and water ad libitum. Animals were anesthetized with intraperitoneal (i.p.) pentobarbital injection $(50 \mathrm{mg} / \mathrm{kg})$. Morris hepatoma cells $\left(5 \times 10^{5}\right)$ in $500 \mu \mathrm{L}$ of serum free media were injected into the inferior pole of the spleen via a 26-gauge needle. The spleen was then returned to the abdomen and the incision was closed.

Twenty-four hours later, animals were randomly divided into five groups and were assigned to receive intrasplenic injections of either PBS (controls), G207 alone, HSV-IL2 alone, mG207/HSV-IL2, or pG207/HSV -IL2 in $500 \mu$ l of PBS. The dose of virus used in each group was $1 \times 10^{6}$ plaque forming units (PFU). For the mG207/HSV-IL2 and pG207/ HSV-IL2 groups the ratio of G207:HSV-IL2 used was kept constant at $1: 1$. Virus was delivered via an intrasplenic injection ( $n=6$ animals per group). Incisions were closed and the animals were returned to their cages. Weights were followed three times per week and when control animals began to lose weight (approximately day 21 after tumor inoculation), animals were killed by $\mathrm{CO}_{2}$ inhalation, their livers harvested, and tumor nodules counted.

\section{Establishment and Treatment of Hepatic Metastases in Mice}

Male Balb/C mice were purchased from the National Cancer Institute (Bethesda, MD, USA), housed five per cage and provided food and water ad libitum. Animals were anesthetized using ketamine and xylazine, administered by i.p. injection $(70 \mathrm{mg} / \mathrm{kg}$ ketamine, $10 \mathrm{mg} / \mathrm{kg}$ xylazine). Using the model described by Lafreniere and Rosenberg (24), $5 \times 10^{4}$ syngeneic murine colon cancer cells (CT-26), in $0.3 \mathrm{ml}$ of serum-free media, were injected into the exteriorized, inferior pole of the spleen through a 26gauge needle. The mice reliably develop on average between 150 and 300 tumor nodules in the liver by 2 weeks after inoculation. The spleen is not removed, however, as to not interfere with the immune response to the tumor in the liver. The incision was closed and $24 \mathrm{hr}$ later the wound was reopened and a single injection of $1 \times 10^{5}, 5 \times 10^{4}$, or $1 \times 10^{4} \mathrm{PFU}$ in $300 \mu \mathrm{l}$ of PBS of the aforementioned viral groups or $300 \mu \mathrm{l}$ PBS alone (controls) was given to six animals per group. The incisions were closed in a similar fashion to that described and returned to their cages. Animal weights were followed closely (three times per week), and when control animals began to lose weight (approximately day 14 after tumor inoculation), animals were killed by $\mathrm{CO}_{2}$ inhalation, livers were harvested, and tumor nodules counted.

\section{$\mathrm{CD}^{+}$and $\mathrm{CD} 8^{+}$T-Lymphocyte Blockade and Its Effect on Hepatic Metastases After Viral Treatment}

Animals were treated with GK1.5 (anti-CD4) and 53-6.72 (anti-CD8) antibodies to deplete CD4 ${ }^{+}$and $\mathrm{CD}^{+} \mathrm{T}$ lymphocytes as previously described (25). Each animal received $0.2 \mathrm{mg}$ of each antibody via i.p. injection daily for 3 consecutive days. The effect of antibody blockade was assessed by FACS analysis 7 days after the first i.p. injection of the antibodies. The blockade was maintained by an i.p. injection of $0.2 \mathrm{mg}$ of each antibody once per week thereafter for 2 weeks until animal sacrifice and liver harvest.

Thirty Balb/c mice were divided evenly into six groups: (1) control (no viral treatment) blocked; (2) control unblocked; (3) mG207/HSV-IL2 blocked; (4) mG207/HSV-IL2 unblocked; (5) pG207/HSV-IL2 blocked; and (6) pG207/HSV-IL2 unblocked. Cells were injected as described previously and therapy delivered $24 \mathrm{hr}$ after inoculation with $5 \times 10^{4} \mathrm{PFU}$ of virus. Animals were killed approximately 14 days after tumor inoculation (when they began to lose weight) and liver nodules counted.

\section{Results}

In Vitro Cytotoxicity

To determine the cytotoxicity of the viral groups, cell survival was measured in vitro by trypan blue exclusion. The HSV-IL2 group did not show any significant cytotoxicity of the Morris hepatoma cell line at any time. At an MOI of 1, the viral groups of G207 alone, mG207/HSV-IL2, and pG207/HSV-IL2 IL-2 showed a $>95 \%$ cell kill of the Morris hepatoma cell line at $72 \mathrm{hr}(p<0.03)$ (data not shown). There was no statistical difference between the in vitro cytotoxic potential of G207, mG207/HSV-IL2, or pG207/ HSV-IL2.

Cell survival was also assayed with the CT-26 cells. The HSV-IL2 group did not demonstrate any significant cytotoxicity on CT-26 cells. At an MOI of 1 , G207 alone demonstrated $>75 \%$ cell kill by $168 \mathrm{hr}$. The packaged and combination groups demonstrated a cell kill of $>90 \%$ by $168 \mathrm{hr}$ for an MOI of 1 . At an MOI of 1, there was statistical significance in in vitro cytotoxic potential when comparing G207, mG207/ HSV-IL2, or pG207/HSV-IL2 groups to controls 


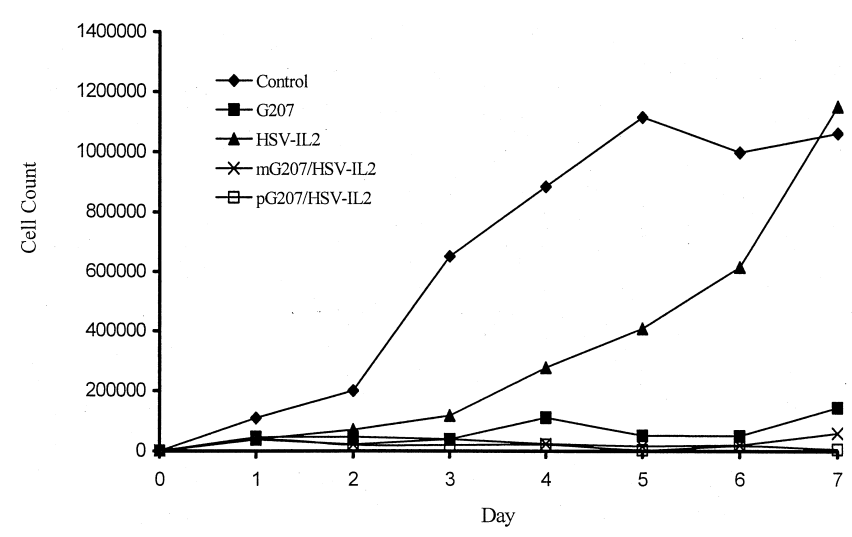

Fig. 1. In vitro cytotoxicity assay. CT-26 cells were plated at a concentration of $5 \times 10^{4}$ cells per well in 12-well plates. Twentyfour hours later the cells were infected with an MOI of 1 of the following: (1) G207 ["], (2) HSV-IL2 [४], (3) mG207/HSV-IL2 [X], (4) pG207/HSV-IL2 [ᄆ], or (5) PBS (controls) [•]. Trypan blue exclusion assay was performed and the viable cells counted. The graph below demonstrates data from a representative cytotoxicity experiment at an MOI of 1 . All assays were performed in triplicate and carried out for 7 days. The cytotoxicity experiments were carried out twice.

$(p<0.04)$ (Fig. 1). There was no statistical difference between the in vitro cytotoxic potential of G207, mG207/HSV-IL2, or pG207/HSV-IL2 (Fig. 1).

\section{In Vitro Production of $I L-2$}

In vitro IL-2 production from the syngeneic murine colorectal cancer cell line CT-26 and Morris hepatoma was determined by sandwich ELISA. Supernatants from the cytotoxicity assay at an MOI of 1 were used to assay for IL-2 production. ELISA performed on the CT-26 cell line showed that the G207 alone group showed no production of IL-2, whereas the HSV-IL-2, mG207/HSV-IL2, and pG207/HSVIL2 groups produced significant amounts of IL-2. Peak levels of IL-2, when normalized to cell count, were seen at $24 \mathrm{hr}$ and then diminished with time. The concentration of IL-2 produced was highest in the HSV-IL2 group $\left(80 \mathrm{pg} / 1 \times 10^{6}\right.$ cells at $\left.24 \mathrm{hr}\right)$. IL-2 produced by the mG207/HSV-IL2 and pG207/ HSV-IL2 groups was in the range of $20-45 \mathrm{pg} / 1 \times 10^{6}$ cells at $24 \mathrm{hr}$. Figure 2 demonstrates IL-2 production, per day, normalized to $1 \times 10^{6}$ cells for an MOI of 1 for the CT-26 cell line only. The Morris hepatoma cell line also produced IL-2 in vitro in picogram quantities. At $24 \mathrm{hr}$ postinfection, IL-2 production was again highest in the HSV-IL2 group (40 pg/le $\mathrm{e}^{6}$ cells). IL-2 produced by the $\mathrm{mG} 207 / \mathrm{HSV}$ IL2 and pG207/HSV-IL2 groups was in the range of $7-20 \mathrm{pg} / 1 \times 10^{6}$ cells.

\section{In Vivo Inhibition of Tumor Growth in Rats}

Buffalo rats were inoculated with Morris hepatoma syngeneic liver carcinoma cells via an intrasplenic injection. Twenty-four hours later therapy was administered intrasplenically. Therapy was given at

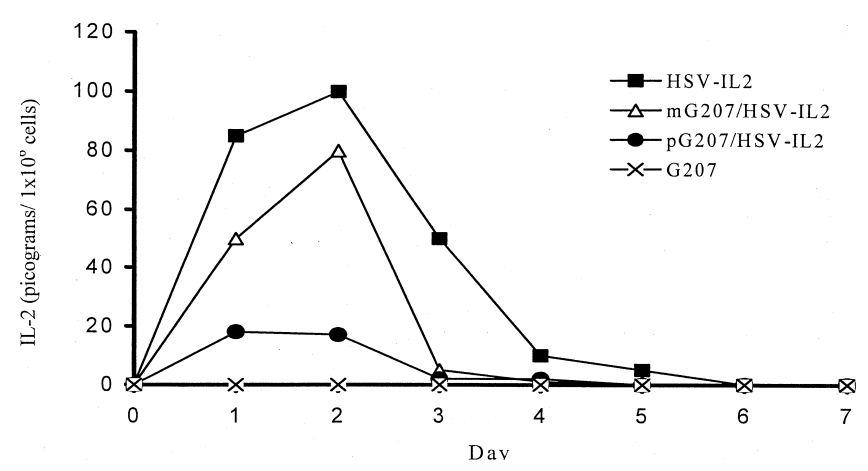

Fig. 2. In vitro production of IL-2. Supernatants were taken from the cytotoxicity assay and IL-2 production assayed for by ELISA. CT-26 cells were plated at a concentration of $5 \times 10^{4}$ cells per well, and infected with the viral groups listed above at a MOI of 1. G207 [X], HSV-IL2 [曰], mG207/HSV-IL2 [४], pG207/HSV-IL2 [•].

$24 \mathrm{hr}$ to simulate a picture of hepatic micrometastases. Rats were treated with either media (controls), G207, HSV-IL2, mG207/HSV-IL2, or pG207/HSVIL2. The dose of virus used was $1 \times 10^{6} \mathrm{PFU}$. This dose reduced tumor burden in all treatment groups, including HSV-IL2 group. The average nodule counts ( \pm SEM) were $288 \pm 76.7$ (controls), $68 \pm 41$ (G207 ), $10 \pm 10$ (HSV-IL2), $58 \pm 24$ (mG207/HSVIL2), and $48 \pm 40$ (pG207/HSV-IL2). There was no statistical significance between treated groups; all the treated groups significantly differed from controls $(p<0.01)$ (Fig. 3).

\section{In Vivo Inhibition of Tumor Growth in Mice}

To assess the anti-tumor efficacy of the viral groupings in vivo, Balb/C mice were inoculated with CT-26 syngeneic colorectal carcinoma via an intrasplenic injection producing hepatic metastases. Twenty-four hours later therapy was administered intrasplenically. Mice were treated with either media (controls), G207, HSV-IL-2, mG207/HSV-IL2, or pG207/ HSV-IL2. At viral concentrations of $1 \times 10^{5} \mathrm{PFU}$ all four treatment groups had significantly fewer hepatic nodules than controls. Control animals had average nodule counts $( \pm$ SEM) of $96.7 \pm 45.5$. Average nodules counts of the treated groups were as follows: G207 [27.24 $55.8(p \leq 0.022)]$, HSV-IL2 [13.08 $\pm 6.6(p \leq 0.013)]$, mG207/HSV-IL2 [11.22 \pm $7.8(p \leq 0.017)]$, and pG207/HSV-IL2 [18.53 \pm 5.6 $(p \leq 0.010)]$ (Fig. 3).

\section{Treatment With Low Dose of Virus in Mice}

The experiment was repeated in Balb/C mice using lower doses of virus to determine if tumor reduction was dose related. Viral doses used in this part of the experiment were $5 \times 10^{4}$ and $1 \times 10^{4}$ PFU for each previously mentioned groups $(n=6$ animals per group). The average hepatic nodule counts from the $5 \times 10^{4}$ PFU treated groups were as follows: Control animals had tumor nodule counts of $284 \pm 7.8$; G207 (270 \pm 24.23); HSV-IL2 (294 \pm 13); mG207/HSV-IL2 

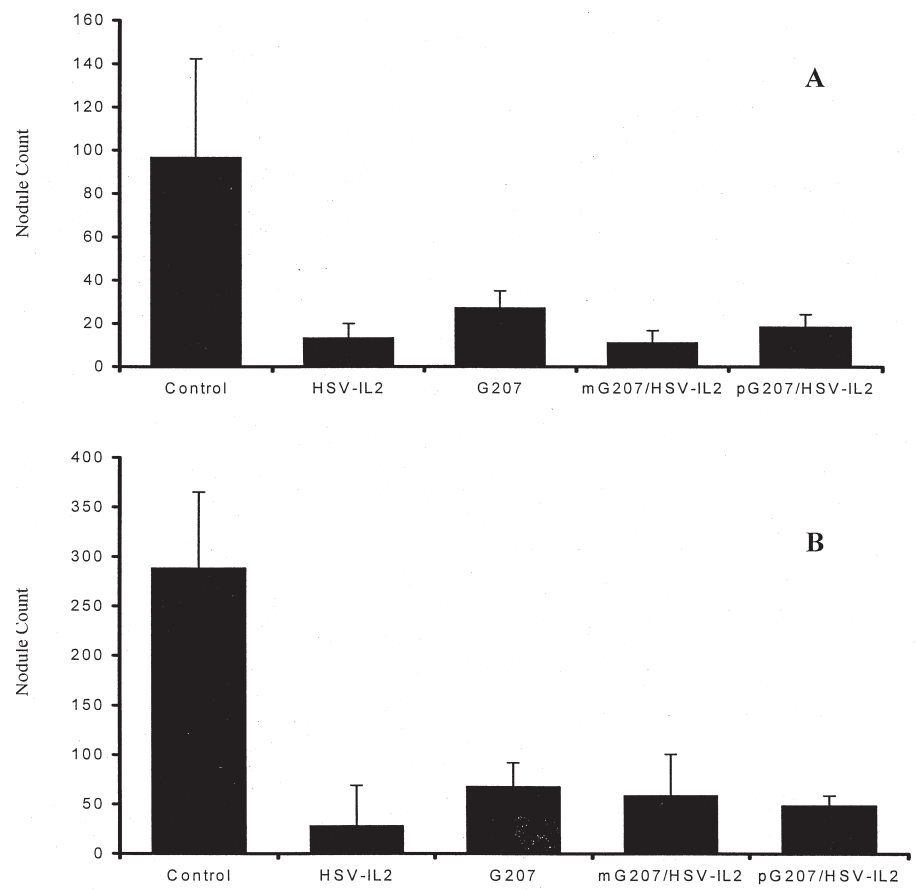

(71.2 \pm 28.3$) ;$ and pG207/HSV-IL2 (64.2 \pm 23$)$. The mG207/HSV-IL2 and pG207/HSV-IL2 treated groups differed significantly from control $(p<0.001)$, while the HSV-IL2 and G207 groups did not differ significantly from control (Fig. 4A).

In animals treated with $1 \times 10^{4} \mathrm{PFU}$ of virus, the nodule counts were similar to those seen with
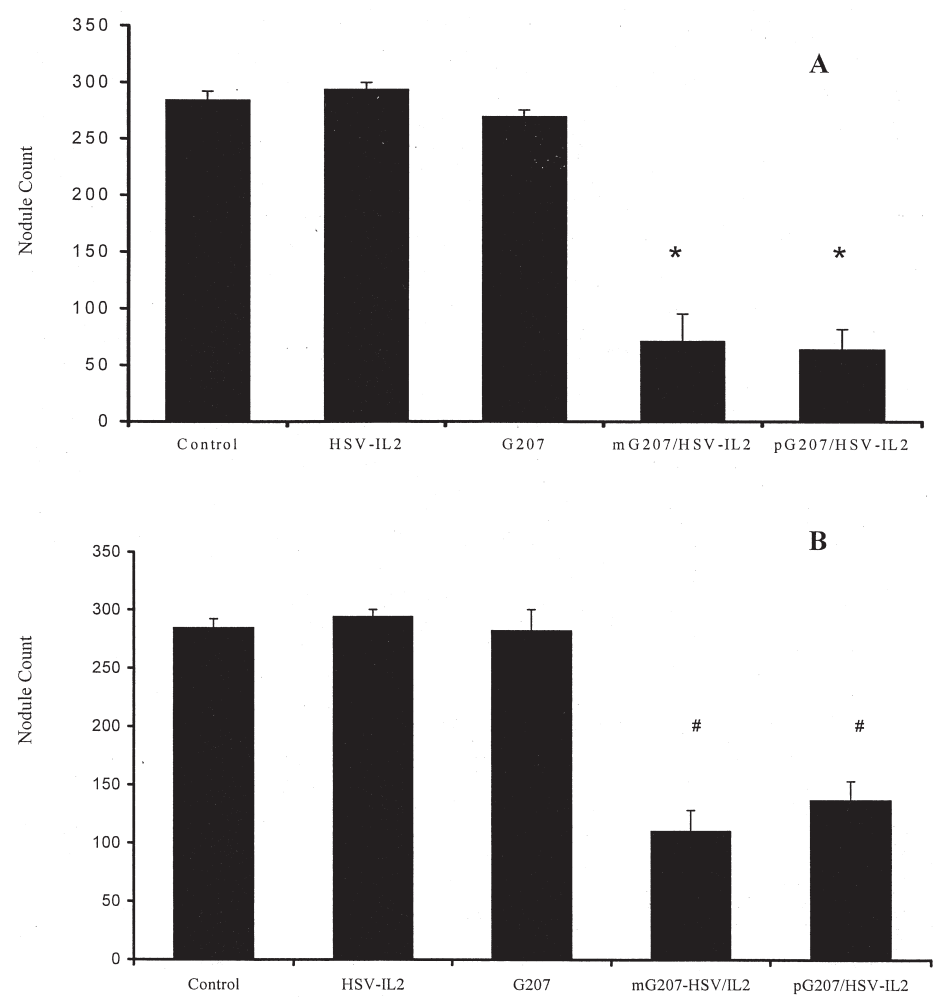

Fig. 3. Average liver tumor nodule count after high-dose viral treatment. (A) Balb/c mice were inoculated intrasplenically with $5 \times 10^{4}$ CT-26 cells. Twenty-four hours later the animals were treated with PBS (controls) or $1 \times 10^{5}$ PFU of the various viral groups ( $n=6$ per group). Livers were harvested at 2 weeks and tumor nodules counted. (B) Buffalo rats were inoculated intrasplenically with $5 \times 10^{5}$ Morris hepatoma cells. Twenty-four hours later the animals were treated with PBS or $1 \times 10^{6} \mathrm{PFU}$ of the various viral groups $(n=6$ per group). Livers were harvested at 3 weeks and tumor nodules counted. All groups differed from controls with $p<0.01$. the $5 \times 10^{4}$ PFU treated groups and were as follows: G207 (282 \pm 18); HSV-IL2 (290 \pm 13.4); mG207/ HSV-IL2 (110.2 \pm 18.1); and pG207/HSV-IL2 $(136.8 \pm 16.4)$. There was a significant difference between high and low doses of virus in the pG207/HSV-IL2 group with a $p$-value of 0.035 (Fig. 4B).

Fig. 4. Average liver tumor nodule count in Balb/c mice inoculated with $5 \times 10^{4}$ CT-26 cells intrasplenically, then treated with a low dose of virus. (A) Mice were treated with PBS (controls) or $5 \times 10^{4} \mathrm{PFU}$ of the viral groups $24 \mathrm{hr}$ after tumor inoculation ( $n=6$ per group). ${ }^{*} p<0.001$ versus control. (B) Mice were treated with PBS or $1 \times 10^{4}$ PFU of virus $24 \mathrm{hr}$ after tumor inoculation ( $n=6$ per group). Livers were harvested at 2 weeks and tumor nodules counted. $\# p<0.002$ versus control. 


\section{$\mathrm{CD}^{+}$and $\mathrm{CD}^{+}$T-Cell Blockade}

To determine if the anti-tumor effect of the combination of the oncolytic virus G207 and the immunostimulatory cytokine IL-2 was mediated by CD4 and CD8 T-cell activation, CD4 and CD8 blockade was performed as described. After confirming blockade by FACS analysis, Balb/c mice were inoculated with $5 \times$ $10^{4}$ CT-26 cells intrasplenically. One day later they were treated with $5 \times 10^{4} \mathrm{PFU}$ of mG207/HSV-IL 2 or pG207/HSV-IL2. The mice were divided into six groups: (1) unblocked (no virus administered) controls; (2) blocked control; (3) unblocked mG207/ HSV-IL2; (3) blocked mG207/HSV-IL2; (4) unblocked pG207/HSV-IL2; and (5) pG207/HSV-IL2. Average tumor nodule counts were as follows: unblocked control, $129 \pm 21$; blocked control, $115.5 \pm 4$; unblocked mG207/HSV-IL2, $28.6 \pm 11$; blocked mG207/HSV-IL2, $91.5 \pm 10$; unblocked pG207/HSV-IL2, $51 \pm 7$; and blocked pG207/HSV-IL2, $106.5 \pm 11$. The unblocked mG207/HSV-IL2 and pG207/HSV-IL2 groups significantly differed from unblocked controls with a $p$-value of 0.003 and 0.01 , respectively. $\mathrm{CD}^{+}, \mathrm{CD}^{+}$T-cell blocked treated groups did not significantly differ from blocked controls. $\mathrm{CD} 4^{+}, \mathrm{CD}^{+}$blockade did not significantly increase or decrease average tumor burden in control animals. Unblocked treated animals had nodule counts that significantly differed from $\mathrm{CD}^{+}$, $\mathrm{CD}^{+}$blocked treated animals $(p<0.01)$ (Fig. 5).

\section{Discussion}

Viruses and viral vectors are central to a number of strategies that have shown promise in treatment of experimental tumors $(4,6,9,11,15,19,26-32)$. In this regard, replication-defective herpes simplex amplicon vectors, as well as replication-competent oncolytic viruses have been shown to be effective as cancer therapy in animal models. HSV amplicon vectors have been used as vehicles for transfer of genes coding cytokines (1), chemokines (33), or costimulatory molecules (8) in immunotherapeutic strategies. Replication-competent oncolytic viruses have also been successfully used for direct killing of a wide variety of tumors including colorectal cancers, prostate cancers, bladder cancer, and brain tumors $(1,3-7,16,34)$. The current study examines the ability to combine these two strategies, and demonstrates that amplicon-mediated immunotherapy in combination with HSV-based oncolytic therapy is highly effective against two different tumor types, in two different species.

The current studies examine two of the most common tumor types encountered. Primary hepatocellular carcinoma occurs in over 1 million individuals yearly and colorectal cancer occurs in over 150,000 individuals in the United States yearly (35-37). Hepatocellular carcinoma often remains confined to the liver even at advanced stages, and the liver is the most common site of metastases from colorectal cancer $(37,38)$. For hepatocellular carcinoma or colorectal cancer, surgery represents the best treatment option, but is only curative in a minority of patients (39-41). For patients with unresectable cancer, chemotherapy or radiation therapy is at best palliative (36). Clearly, novel therapies are needed in the treatment of these common cancers. Choice of the liver tumor models results from potential clinical relevance due to common occurrence of cancer at this organ site. Previous studies have demonstrated that herpes-based oncolytic therapies can successfully lyse hepatocellular carcinoma cells or colorectal cancer cells in vitro, and are promising in animal models $(4,16,32)$. The current study demonstrates that the addition of local cytokine gene transfer adds to the efficacy of regionally delivered oncolytic therapy and suggests that this combination may be promising. In addition, these well-established models allow the study of vascular delivery of viral therapies that have general implications for such novel therapies.

Previous studies of delivery of oncolytic therapy and local cytokine production have attempted direct injection of tumors implanted subcutaneously within the flank $(9,18)$. Although these other studies are a "proof of principle" that when such combined therapies are adequately delivered to tumor targets an exaggerated anti-tumor response is seen, direct injection of tumors is a clinically relevant method only for a very limited number of tumors such as brain cancers. For most other tumors, if limited

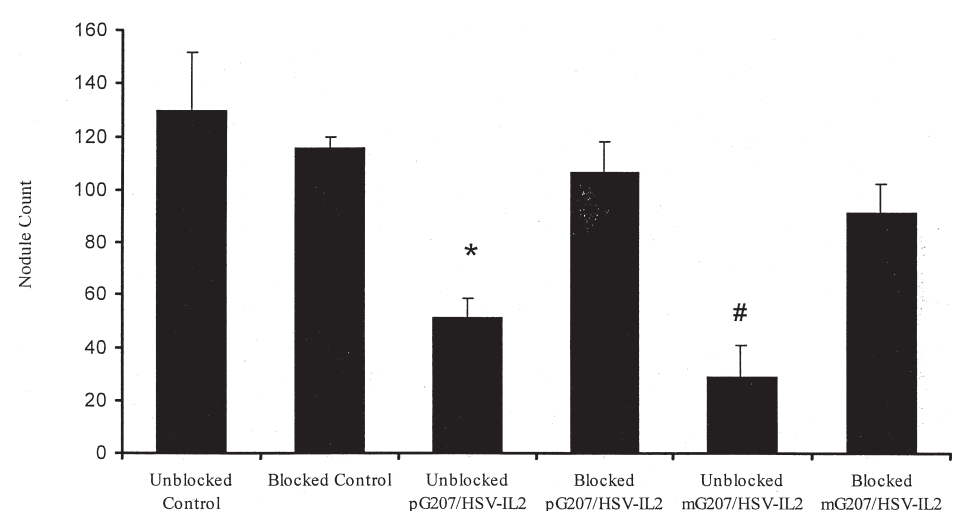

Fig. 5. $\mathrm{CD}^{+}$and $\mathrm{CD}^{+}$T-cell blockade. Balb/c mice were injected i.p. with $0.2 \mathrm{mg}$ of anti-CD4 (GK 1.5) and anti-CD8 (53-1.62) antibodies for 3 consecutive days. T-cell inactivation was assessed by FACS analysis 7 days after last injection. The mice were inoculated with $5 \times 10^{4} \mathrm{CT}-26$ cells intrasplenically and then treated with either mG207/HSV-

IL2 or pG207/HSV-IL2 at $5 \times 10^{4} \mathrm{PFU} 24 \mathrm{hr}$ later. Mice were divided equally into six groups $(n=5$ per group): both blocked and unblocked control, mG207/HSV-IL2 and pG207/HSV-IL2 groups. Livers were harvested at 2 weeks and tumor nodules counted. Unblocked mG207/HSV-IL2 and unblocked pG207/HSV-IL2 groups significantly differed from controls with $p$-values of 0.003 and 0.01 , respectively. Blocked mG207/HSV-IL2 and blocked pG207/HSV-IL2 groups did not significantly differ from blocked controls. ${ }^{\star} p<0.01$ versus control. $\# p<0.003$ versus control. 
disease is encountered that can be treated by direct injection, surgical excision is generally a simpler and more effective alternative. Data from the current studies indicate that combined oncolytic and immuno therapies can be achieved by the more clinically relevant vascular delivery.

The major goal of combining two diverse strategies is clearly to increase anti-tumor efficacy. Equally important, however, is the goal of reducing the need for each virus to achieve anti-tumor efficacy. In the past, when attempts have been made to use various chemotherapies in combined treatment of cancer, efforts have usually been made to achieve the highest dose of each that is tolerable. When combining oncolytic viral therapy with amplicon vector-mediated cytokine gene transfer, using the highest tolerable dose of each virus may not produce optimal efficacy. An overly vigorous initial oncolysis may reduce cytokine production. Furthermore, in the in vivo models, when viruses are administered at high doses the oncolytic effects were sufficiently vigorous that we were unable to demonstrate an advantage from addition of local cytokine gene transfer. Indeed, it was in an experiment using low doses of oncolytic virus and amplicon vectors that the greatest benefit of combined therapy was noted. Thus, the advantage of such a combined approach likely will be the reduction of doses of the viral agents needed.

One alternative strategy for combining oncolytic therapy with immunostimulatory therapy is to engineer an oncolytic virus that contains a transgene coding an immunostimulatory molecule (42). The methods tested in the current paper of mixing amplicon with oncolytic virus or indeed packaging amplicon using oncolytic virus as helper virus have important practical implications for preclinical studies and clinical trials. First, mixing the various oncolytic viruses and amplicon vectors is simple. Therefore, numerous amplicons with various immunostimulatory genes including cytokines, chemokines, adhesion molecules, or costimulatory molecules can be separately prepared to clinical grade and tested in preclinical toxicology. These can then be simply mixed with various oncolytic viruses for administration. Various combinations, various relative dosages, staggered administration, and varied sequence of administration can then be tested with relative ease. Only when the optimal combinations are proven will it be necessary to commit to a single oncolytic virus carrying the optimal transgenes with appropriate promoter strengths. This study therefore reports data highly encouraging for clinical investigations using regional vascular delivery of HSV oncolytic viruses coupled with HSV amplicons carrying transgenes for the treatment of cancer.

\section{Acknowledgments}

Supported in part by grants RO1 CA 75416, RO1 CA 72632, and ROICA61524 (Y.F.) from the National
Institutes of Health and Grant MBC-99366 (Y.F.) from the American Cancer Society.

\section{References}

1. Karpoff HM, D'Angelica M, Blair S, Brownlee MD, Federoff $\mathrm{H}$, Fong Y. (1997) Prevention of hepatic tumor metastases in rats with herpes viral vaccines and gamma-interferon. J. Clin. Invest. 99: 799-804.

2. Fong Y, Federoff HJ, Brownlee M, Blumberg D, Blumgart LH, Brennan MF. (1995) Rapid and efficient gene transfer in human hepatocytes by herpes viral vectors. Hepatology 22: 723-729.

3. Kirn DH, McCormick F. (1996) Replicating viruses as selective cancer therapeutics. Mol. Med. Today 2: 519-527.

4. Kooby D, Carew J, Halterman M, et al. (1999) Oncolytic viral therapy for human colorectal cancer and liver metastases using a multi-mutated herpes simplex virus type-1 (G207). FASEB J. 13: 1325-1334.

5. Yoon S, Carroll NM, Chiocca EA, Tanabe KK. (1998) Cancer gene therapy using a replication-competent herpes simplex virus type 1 vector. Ann. Surg. 228: 366-374.

6. Bennett JJ, Kooby DA, Delman K, et al. (2000) Antitumor efficacy of regional oncolytic viral therapy for peritoneally disseminated cancer. J. Mol. Med. 78: 166-174.

7. Yoon S, Nakamura H, Carroll NM, Bode BP, Chiocca EA, Tanabe KK. (2000) An oncolytic herpes simplex virus type l selectively destroys diffuse liver metastases from colon carcinoma. FASEB J. 14: 301-311.

8. D'Angelica M, Tung C, Allen P, et al. Herpes Simplex Virus (HSV)- mediated ICAM-1 gene transfer abrogates tumorigenicity and induces anti-tumor immunity. Mol. Med. 5: 606-616.

9. Tung C, Federoff HJ, Brownlee M, et al. Rapid production of interleukin-2-secreting tumor cells by herpes simplex virusmediated gene transfer: implications for autologous vaccine production. Hum. Gene Ther. 7: 2217-2224.

10. Karpoff HM, Tung C, Ng B, Fong Y. (1996) Interferon gamma protects against hepatic tumor growth in rats by increasing Kupffer cell tumoricidal activity. Hepatology 24: 374-379.

11. Toda M, Martuza RL, Kojima H, Rabkin SD. (1998) In situ cancer vaccination: an IL-12 defective vector/replicationcompetent herpes simplex virus combination induces local and systemic antitumor activity. J. Immunol. 160: 4457-4464.

12. Caruso M, Nguyen K, Kwong Y, et al. Adenovirus-mediated interleukin-12 gene therapy for metastatic colon carcinoma. Proc. Natl. Acad. Sci. U.S.A. 93: 11302-11306.

13. Geshwind MD, Kessler JA, Geller AI, Federoff H. (1994) Transfer of the nerve growth factor gene into cell lines and cultured neurons using a defective herpes simplex virus vector. Transfer of the NGF gene into cells by a HSV-1 vector. Brain Res. Mol. Brain Res. 24: 327-335.

14. Jarnagin WR, Delman K, Kooby DA, et al. Neoadjuvant inteleukin-12 immunogene therapy protects against cancer recurrence after liver resection in an animal model. Ann. Surg. 231: 762-771.

15. Kenney S, Pagano JS. (1994) Viruses as oncolytic agents: a new age for "therapeutic" viruses? J. Natl. Cancer Inst. 86: $1185-1186$.

16. Delman K, Bennett J, Zager JS, et al. (2000) Effects of preexisting immunity on the response to herpes simplex based oncolytic viral therapy. Hum. Gene Ther. 11: 2465-2472.

17. Kramm CM, Rainov NG, Sena-Esteves M, et al. (1996) Herpes vector-mediated delivery of marker genes to disseminated central nervous system tumors. Hum. Gene Ther. 7: 291-300.

18. Toda M, Martuza RL, Kojima H, Rabkin SD. (1998) In situ cancer vaccination: an IL-12 defective vector/replicationcompetent herpes simplex virus combination induces local and systemic antitumor activity. J. Immunol. 160: 4457-4464.

19. Carew JF, Kooby DA, Halterman MW, Federoff H, Kim SH, Fong Y. (in press) Combination therapy utilizing an oncolytic virus and a replication incompetent vector carrying an immunoregulatory transgene for the treatment of squamous cell carcinoma. Mol. Ther. 
20. Andreansky S, He B, van Cott J, et al. (1997) Treatment of intracranial gliomas in immunocompetent mice using herpes simplex viruses that express murine interleukins. Gene Ther. 8: $121-130$.

21. Bergold PJ, Casaccia-Bonnefil P, Zeng XL, Federoff H. (1993) Transsynaptic neuronal loss induced in hippocampal sliced cultures by a herpes simplex virus vector expressing the GluR6 subunit of the kainate receptor. Proc. Natl. Acad. Sci. U.S.A. 90: 6165-6169.

22. Geshwind MD, Hartnick CJ, Liu W, Amat J, Van De Water TR, Federoff H. (1996) Defective HSV-l vector expressing BDNF in auditory ganglia elicits neurite outgrowth: model for treatment of neuron loss following cochlear degeneration. Hum. Gene Ther. 7: 173-182.

23. Mineta T, Rabkin SD, Yazaki T, Hunter WD, Martuza RL. (1995) Attenuated multi-mutated herpes simplex virus-1 for the treatment of malignant gliomas. Nat. Med. 1: 938-943.

24. Lafreniere R, Rosenberg SA. (1986) A novel approach to the generation and identification of experimental hepatic metastases in a murine model. J. Natl. Cancer Inst. 76: 309-322.

25. Kruisbeek AM. (1994) In vivo depletion of CD4+ and CD8+ specific T cells. In: Coligan J, Kruisbeek AM, Margulies D, Sherach E, Strober W, eds. Current protocols in immunology. New York: John Wiley \& Sons; pp. 4.1.1-4.1.5.

26. Heise C, Sampson-Johannes A, Williams A, McCormick F, Von Hoff DD, Kirn DH. (1997) ONYX-015, an ElB geneattenuated adenovirus, causes tumor-specific cytolysis and anti-tumoral efficacy that can be augmented by standard chemotherapeutic agents. Nat. Med. 3: 639-645.

27. Mineta T, Markert JM, Takamiya Y, Coen DM, Rabkin SD, Martuza RL. (1994) CNS tumor therapy by attenuated herpes simplex viruses. Gene Ther. 1(Suppl 1): S78.

28. Toda M, Rabkin SD, Kojima H, Martuza RL. (1999) Herpes simplex virus as an in situ cancer vaccine for the induction of specific anti-tumor immunity. Hum. Gene Ther. 10: 385-393.

29. Carew JF, Kooby DA, Halterman MW, Federoff HJ, Fong Y. (1999) Selective infection and cytolysis of human head and neck squamous cell carcinoma with sparing of normal mucosa by a cytotoxic herpes simplex virus type 1. Hum. Gene Ther. 10: 1599-1606.
30. Meigner B, Longnecker R, Roizman B. (1988) In vivo behavior of genetically engineered herpes simplex viruses $\mathrm{r} 7017$ and r7020: construction and evaluation in rodents. J. Infect. Dis. 158: $602-614$.

31. Hunter WD, Martuza RL, Feigenbaum F, et al. Attenuated, replication-competent herpes simplex virus type 1 mutant G207: safety evaluation of intracerebral injection in nonhuman primates. J. Virol. 73: 6319-6326.

32. Yoon S, Nakamura H, Carroll NM, Bode BP, Chiocca EA, Tanabe KK. (2000) An oncolytic herpes simplex virus type l selectively destroys diffuse liver metastases from colon carcinoma. FASEB J. 14: 301-311.

33. Kutubuddin $M$, Federoff $H$, Challita-Eid PM, et al. Eradication of pre-established lymphoma using herpes simplex virus amplicon vectors. Blood 93: 643-654.

34. Martuza RL, Malick A, Markert JM, Ruffner K, Coen DM. (1991) Experimental therapy of human glioma by means of a genetically engineered virus mutant. Science 252: 854-856.

35. Landis SH, Murray T, Bolden S. (1998) Cancer statistics, 1998. CA Cancer J. Clin. 48: 6-29.

36. Kemeny N, Huang Y, Cohen AM, et al. (1999) Hepatic arterial infusion of chemotherapy after resection of hepatic metastases from colorectal cancer. N. Engl. J. Med. 341: 20392048.

37. Greenlee RT, Murray T, Bolden S, Wingo PA. (2000) Cancer statistics, 2000. CA Cancer J. Clin. 50: 7-33.

38. Fong Y, Kemeny N, Paty P, Blumgart LH, Cohen AM. (1996) Treatment of colorectal cancer: hepatic metastasis. Semin. Surg. Oncol. 12: 219-252.

39. Fong Y, Cohen AM, Fortner JG, et al. (1997) Liver resection for colorectal metastases. J. Clin. Oncol. 15: 938-946.

40. Guillem JG, Paty PB, Cohen AM. (1997) Surgical treatment of colorectal cancer. CA Cancer J. Clin. 47: 113-128.

41. Fong Y, Salo J. (1999) Surgical therapy of hepatic colorectal metastasis. Semin. Oncol. 26: 514-523.

42. Parker JN, Gillespie GY, Love CE, Randall S, Whitley RJ, Markert JM. (2000) From the cover: engineered herpes simplex virus expressing IL-12 in the treatment of experimental murine brain tumors. Proc. Natl. Acad. Sci. U.S.A. 97: 22082213. 